\title{
Perancangan Website Dengan Menggunakan Content Management System Dengan Model View Controller Pada Taman Kanak-Kanak
}

\author{
Halim Maulana ${ }^{1 *}$, Al-Khowrizmi ${ }^{2}$ \\ 1,2 Sistem Informasi, Fakultas Ilmu Komputer dan Teknologi Informasi \\ ${ }^{1,2}$ Universitas Muhammadiyah Sumatera Utara, Jl. Kapten Muchtar Basri No.3 \\ *e-mail : halimmaulana@umsu.ac.id
}

\begin{tabular}{l} 
Informasi Artikel \\
\hline Diterima Redaksi: \\
Revisi Akhir: \\
Diterbitkan Online: \\
Kata Kunci: \\
(Taman Kanak Islam, Website, Informasi, Content \\
Management System, Model View Controller)
\end{tabular}

\section{PENDAHULUAN}

Dengan adanya suatu sistem informasi dapat membantu dalam pengembangan mutu maupun kinerja dari sebuah sekolah. Karena sistem informasi digunakan untuk menampilakan informasi dengan cepat tanpa adanya redudansi yang tidak diperlukan. Juga dengan adanya sistem berbasis komputer maupun sistem informasi dapat menghindari kesalahan-kesalahan yang disebabkan oleh user atau pegawai, staf dan manager. Selain daripada cepat dan mudah dalam menampilkan informasi yang baru oleh adanya update data yang dilakukan admin, sistem informasi juga memberikan keringanan dalam menghemat suatu biaya pengalokasian ruang dimana biasanya digunakan sebagai tempat pengarsipan dari sistem manual. Hal tersebut terjadi dikarenakan oleh adanya database berupa kumpulan data yang telah diolah dan disimpan dalam komputer. Pada saat ini banyak sekolah menggunakan sistem informasi untuk memperoleh informasi yang
Abstrak

TK Kartini dan TK. Al-Atfal Qusqazah merupakan suatu TK yang bergerak dalam bidang pendidikan di Sumatera Utara. Untuk meningkatkan pendidikan di sumatera utara diperlukan informasi-informasi. Untuk menyampaikan informasi, TK ini masih menggunakan sistem manual baik flyer ataupun iklan koran. Penerapan sebuah website yang berisi informasi digital terkait informasi TK dan murid-murid adalah sebuah langkah yang paling tepat untuk mendorong kemajuan daripada keberlangsungan TK tersebut. Dengan memanfaatkan Conten Management System pegawai TK Kartini dapat dengan mudah mengisi dan mengatur data atupun informasi terkait dari TK tersebut walaupun pegawai TK tersebut tidak memilki kemampuan ataupun pengetahuan di bidang IT. Dengan Menerapkan sistem tersebut didalam website tersebut, TK Kartini dan TK. Al-Atfal Qusqazah akan menjadi lebih informatif dalam menyampaikan informasi yang dapat di akses oleh publik melalui jaringan internet baik di akses melalui perangkat komputer atau laptop , smartphone ataupun tablet

digunakan oleh berbagai level pegawai sekolah/tk dan guru guru. Para staf menggunakan informasi dari komputer untuk mempercepat pelayanan kepada pelanggan atau untuk kepentingan internal maupun manajemen. Dengan adanya sistem informasi tersebut, mereka dapat memberikan respon dengan cepat karena informasi bisa ditayangkan pada layar dengan sangat mudah dan cepat berkat adanya data yang tersimpan dalam database. Para pegawai dan bahkan murid pun mudah dalam pengambilan keputusan juga berkat kemudahan memperoleh informasi yang dihasilkan oleh sistem berbasis komputer.

TK Kartini dan TK. Al-Atfal Qusqazah merupakan suatu TK yang bergerak dalam bidang pendidikan di sumatera utara Medan. Untuk meningkatkan pendidikan di sumatera utara diperlukan informasiinformasi. Untuk menyampaikan informasi, TK ini masih menggunakan sistem manual baik flyer ataupun iklan koran. 
Penerapan sebuah website yang berisi informasi digital terkait informasi TK dan murid-murid adalah sebuah langkah yang paling tepat untuk mendorong kemajuan daripada keberlangsungan TK tersebut. Dengan memanfaatkan Conten Management System pegawai TK Kartini dapat dengan mudah mengisi dan mengatur data atupun informasi terkait dari TK tersebut walaupun pegawai TK tersebut tidak memilki kemampuan ataupun pengetahuan di bidang IT. Dengan Menerapkan sistem tersebut didalam website tersebut, TK Kartini akan menjadi lebih informatif dalam menyampaikan informasi yang dapat di akses oleh publik melalui jaringan internet baik di akses melalui perangkat komputer atau laptop, smartphone ataupun tablet.

\subsection{Kondisi Mitra}

Pada saat ini TK. Kartini dan TK. AlAtfal Qusqazah merupakan Taman Kanak yang baru berdiri dan masih belum dikenal di masyarakat. Saat ini Taman Kanak Islam tersebut telah memiliki sarana dan prasanayang cukup yang terdiri dari tempat bermain, ruang belajar, tempat sholat, kamar mandi untuk di gunakan oleh siswa dan guru tersebut. Pada data terakhir menurut dapodik paud tk tersebut masing-masing memiliki 2 rombongan belajar di masing tahun ajaran dan akan terus meningkat di waktu kedepannya. Jumlah guru yang ada di TK tersebut terdapat 4 Guru dan 1 operator untuk TK. Kartini dan 5 Guru untuk TK. AlAtfal Qusqazah.

\subsection{Permasalahan}

Di dalam era digitilisasi tentunya banyak tantangan dan rintangan yang di hadapi tingkat pendidikan termasuk juga taman kanak-kanak. Terlebih lagi di situasi pandemi seperti ini yang semua kegiatan di batasi kontak pisik juga sangat di perhatikan. Walaupun pemerintah juga melakukan sosialisasi New Normal [1][2] akan tetapi tidak serta merta kita langsung bebas dengan tidak memperhatikan protokol keamanan. Di dalam penyebaran informasi terkait tk , kedua Taman Kanak Islam tersebut masih melakukan metode manual untuk kegiatan promosi di karenakan taman kanak tersebut belum memiliki sebuah website sebagai wadah untuk menyampaikan informasi kepada masyarakat. Sehingga tim pengabdian masyarakat menyimpulkan bahwa ketidaksiapan taman kanak tersebut dalam bidang teknologi seperti tidak memiliki website sebagai media pengantar informasi sebagai permasalahan yang cukup penting untuk di selesaikan.

\subsection{Rencana Permasalahan}

Untuk menyelesaikan permasalahan yang ada, maka dilakukan kegiatan sebagai berikut :

1. Melakukan pengumpulan data terkait Kedua Taman Kanak Kanak TK. Kartini dan Tk. Al. Atfal Quzqazah.

2. Melakukan perancangan tampilan website Kedua Taman Kanak Kanak TK. Kartini dan Tk. Al. Atfal Quzqazah.

3. Melakukan Upload website publik dengan menggunakan Host dan Domain

\subsection{Tinjauan Pustaka}

a. Website

Web adalah salah satu aplikasi atau sistem yang di dalamnya berisikan dokumendokumen multimedia (teks, gambar, suara, animasi, video) di dalamnya yang mengunakan protokol HTTP (hypertext transfer protokol) dan untuk mengakses website tersebut menggunakan perangkat lunak yang disebut browser". Fungsi website diantaranya [3][4] :

1. Media Promosi

2. Media Pemasaran

3. Media Informasi

4. Media Pendidikan

5. Media Komunikasi

b. PHP

PHP (Hypertext Preprocessor), merupakan bahasa pemrograman pada sisi server yang memperbolehkan programmer menyisipkan perintah - perintah perangkat lunak web server (apache, IIS, atau apapun) akan dieksekusi sebelum perintah itudikirim oleh halaman ke browser yang me-request-nya, contohnya adalah bagaimana memungkinkannya memasukkan tanggal sekarang pada sebuah halaman web setiap kali tampilan tanggal dibutuhkan. Sesuai dengan fungsinya

yang berjalan di sisi server maka PHP adalah bahasa pemrograman yang digunakan untuk membangun teknologi web application [5][6] 
c. MySql

My SQL (My Structure Query Language) adalah adalah sebah aplikasi atau sistem untuk mengelola suatu database atau manajemen data. Untuk menyimpan segala informasi kekomputer mengunakan data. MYSQL bertugas mengatur dan mengelola data-data pada database, selain itu MYSQL dikenal sebagai sistem yang efisien dan reliable, proses query cepat dan mudah, sehingga cocok digunakan untuk aplikasi berbasis web[7][8].

Fungsi dari SQL, kita dapat melakukan halhal berikut:

1. Memodifikasi struktur database .

2. Mengubah, mengisi, menghapus isi database

3. Mentransfer data antara database yang berbeda

d. Promosi

Promosi , kata promosi berasal dari kata promote dalam bahasa Inggris yang diartikan sebagai mengembangkan atau meningkatkan. Promosi merupakan salah satu komponen atau bagian dari bauran pemasaran (marketing mix). Promosi dapat juga diartikan sebagai upaya untuk memberitahukan atau menawarkan produk atau jasa pada dengan tujuan menarik calon konsumen untuk membeli atau mengkonsumsinya. Dengan adanya promosi produsen atau distributor mengharapkan kenaikannya angka penjualan. Fungsi promosi dalam bauran pemasaran adalah untuk mencapai berbagai tujuan komunikasi dengan konsumen. [9][10]

\section{METODE}

Metode yang di digunakan di dalam pengabdian ini dimulai dari peninjauan mitra yang bertujuan untuk mengetahui permasalaan yang ada pada mitra, dari tinjauan yang kami lakukan akan susun proposal, yang bertujuan untuk mempermudah pembuatan sistem dan modul, persiapan komponen untuk pelatihan sangat penting pada saat pelaksaan pelatihan di tempat mitra, evaluasi sangat di perlukan setelah melakukan pengabdian sehingga tim mengetahui sejauh mana progress yang kami jalannkan sebelum di buatkan laporan akhir dari pengabdian. Metode yang digunakan dalam melaksanakan penelitian merupakan dasar penyusunan rancangan penelitian.
Penelitian dan pengamatan yang dilakukan adalah tentang apa yang menjadi permasalahan dan kebutuhan pada Taman Kanak Islam.

\subsection{Penyelesaian Masalah}

Untuk dapat memberikan solusi yang di butuhkan terhadap permasalahan yang ada, dilakukan berbagai langkah sebagai berikut :

1. Pengumpulan data-data terkait TK mitra

2. Perancangan Dan Desain Website

3. Upload Website ke Publik dengan menggunakan Host dan Domain

4. Sosialisasi kepada Pihak TK. Kartini dan TK. Al Atfal Quzqazah

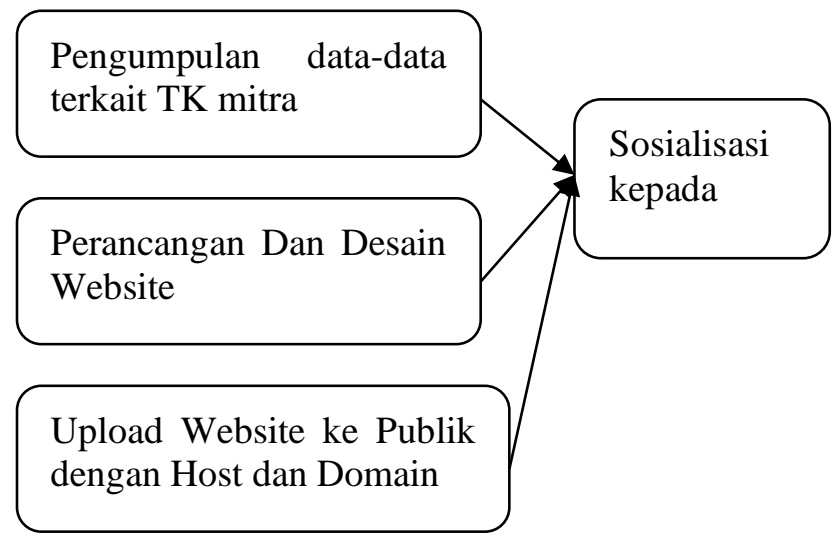

Gambar 1. Diagram Tahapan Pelaksanaan

Pada Gambar 1 terdapat diagram ilustrasi proses pengembangan dan peracangan website pada Mitra.

\section{b. Kebutuhan Perangkat Lunak}

Perangkat lunak merupakan penunjang dari peralatan komputer yang akan digunakan sebagai penghubung dalam instruksi yang diinginkan [11], agar komputer dapat menghasilkan informasi yang diharapkan, maka perangkat lunak yang diusulkan dalam rancangan untuk membangun website tersebut adalah sebagai berikut:

1. Sistem Operasi Windows 10

2. Sublime Text

3. Xampp Control Panel v7

4. Chrome Browser 


\section{b. Kebutuhan Perangkat Keras}

Perangkat keras yang dibutuhkan oleh sistem adalah suatu unit personal komputer. Perangkat keras yang diusulkan ini dibuat berdasarkan kebutuhan sistem saat ini dan antisipasi kebutuhan di masa yang akan datang. Konfigurasi yang dibutuhkan pada design sistem yang diusulkan dalam merancang website tersebut [12][13], yaitu:

1. Laptop / PC

2. Processor Core i5

3. RAM : $4.00 \mathrm{~GB}$

4. Harddisk : $1 \mathrm{~GB}$

5. System Type : 64 bit Operating

\section{HASIL DAN PEMBAHASAN}

\subsection{Tampilan Website}

Website Taman Kanak tersebut dapat di akses melalui masing-masing link https://tkislamkartini.sch.id dan https://tkislamalatfalquzqazah.sch.id

a. Tampilan Beranda

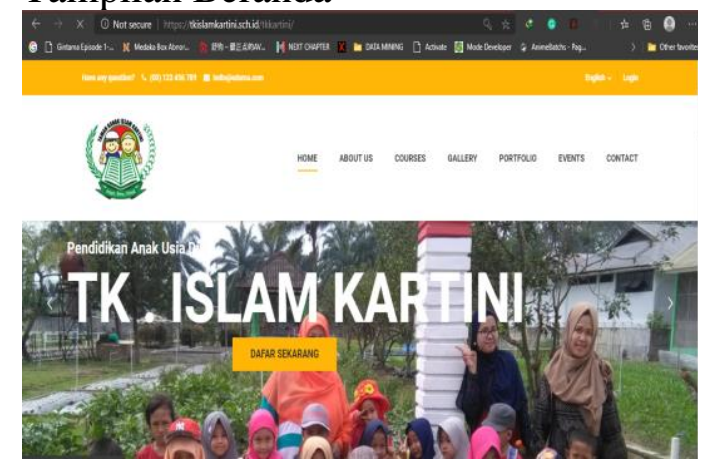

Gambar 2. Tampilan Beranda

Pada gambar 2 merupakan tampilan beranda yang di tampilkan ketika pertama kali website di buka yang menampilkan informasi terkini dari TK tersebut

b. Tapilan About

Pada gambar 3 di bawah merupakan tampilan informasi tentang profil TK dan informasi terkait lembaga dan pendirian Lembaga.
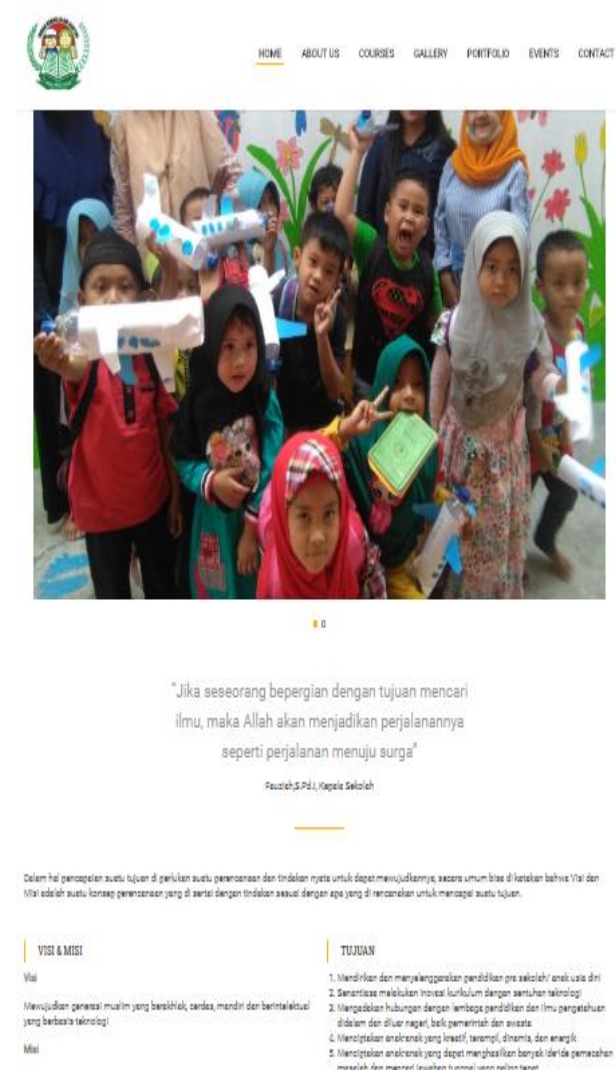

Gambar 3. Tampilan About

c. Tampilan Course/Kelas

Pada gambar 4 merupakan jenisjenis layanan yang terdapat pada TK mitra seluruh pilihan layanan akan di tampilkan pada menu ini

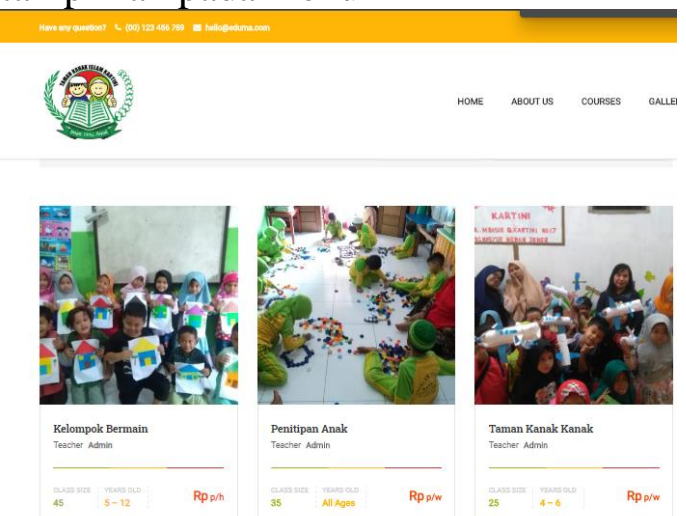

Gambar 4. Tampilan Course Kelas

d. Tampilan Gallery

Pada Gambar 5 adalah tamplan gallery ataupun gambar-gambar pilihan dari TK yang dapat membantu pihak orang tua untuk melihat apa saja kegiatn yang di lakukan di TK tersebut. 


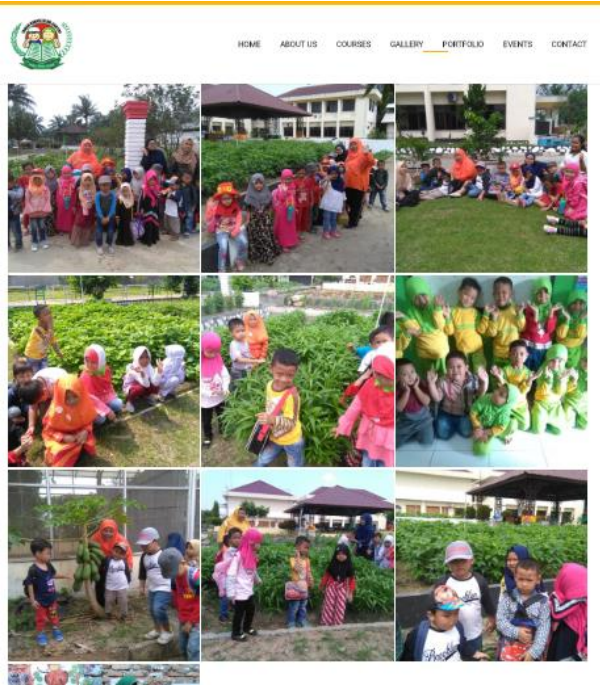

Gambar 5. Tampilan Gallery

e. Tampilan Kontak

Menu terakhir adalah tampilan halaman kontak. Pada halaman ini menampilkan informasi alamat dan informasi kontak serta dapat mengirimkan pertanyaan terkait TK.

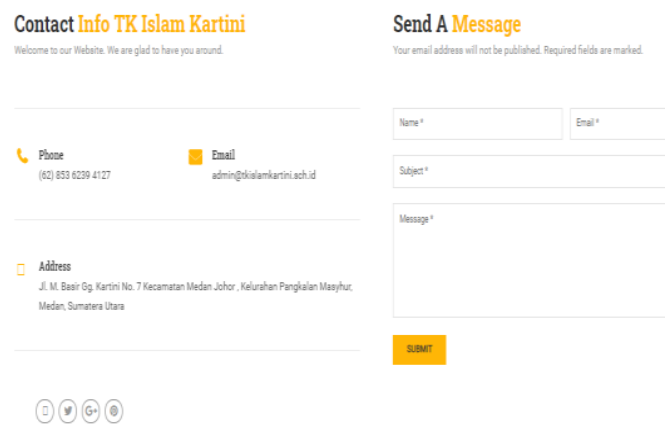

Gambar 6. Tampilan Kontak

\subsection{Pelaksanaan Kegiatan}

Setelah melakukan proses yang telah di jabarkan pada bagian sebelumnya maka proses pelakasaanan di lakukan dengan cara langsung terjun kelokasi yang dilaksanakan pada bulan Juni 2020.

1. Kegiatan Penginputan Data TK

Sebelum dapat di publikasikan website tersebut kepada masyarakat terlebih dahulu di lakukan proses penginputan data oleh pihak admin/operator masing-masing TK Mitra.

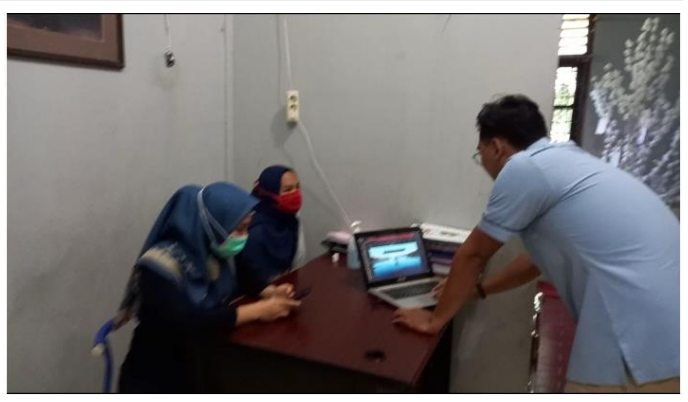

Gambar 2. Penginputan data TK

\section{Sosialisasi Webisite Pada Mitra}

Setelah data yang di butuhkan telah selesai di input kedalam sistem website maka selanjutnya di lakukan proses sosialisasi kepada pihak mitra terkait pengelolaaan website tersebut

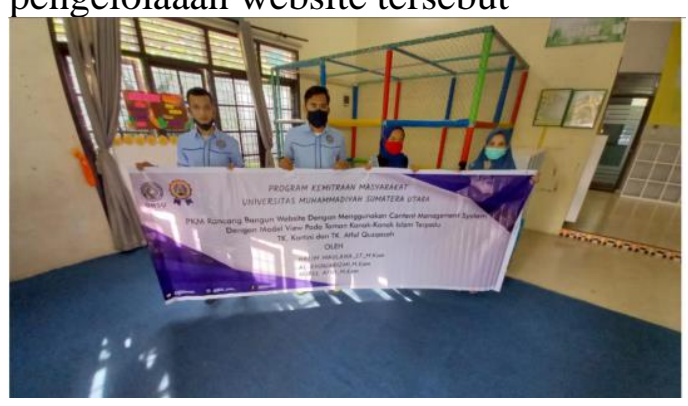

Gambar 3. Sosialisasi Webiste Pada Mitra

\subsection{Dampak yang di harapkan}

Diharapkan dengan adanya media website ini pihak TK Mitra menjadi lebih aktif di dalam memasarkan atau promosi TK tersebut kepada masyarakat dan informasi terkait Taman Kanak Kanak Tersebut dapat dengan mudah di akses oleh publik/masyarakat

\section{KESIMPULAN}

Telah terbangun website yang sedang aktif di gunakan oleh TK. Kartini dan TK. Al-Atfal Quzqazah. Dimana dengan adanya website tersebut pihak TK sudah mulai aktif di dalam mengikuti perkembangan teknologi dan menggunakan media teknologi sebagai metode penyampaian informasi kepada masyarakat.

\section{SARAN}

Untuk kedepannya mungkin dapat di bangun sistem penerimaan siswa baru melalui sistem online sehingga dapat 
memudahkan calon siswa dan proses administrasi di TK tersebut

\section{UCAPAN TERIMA KASIH}

Puji Syukur kita haturkan ke hadirat Allah SWT atas selesainya kegiatan pengabdian kepada masyarakat ini, tidak lupa, kami juga mengucapkan terima kasih kepada pihak yang telah membantu atas terselenggaranya kegiatan ini, diantaranya :

1. Bapak Rektor Universitas Muhammadiyah Sumatera Utara

2. Ketua LPPM Universitas Muhammadiyah Sumatera Utara

3. Kepala Sekolah TK. Kartini

4. Kepala Sekolah TK. Al-Atfal Quzqazah5. Pihak-pihak yang telah mendukung berjalannya kegiatan ini yang tidak dapat kami sebutkan satu-persatu.

\section{REFERENSI}

[1] Buana, Dana Riksa, "Analisis Perilaku Masyarakat Indonesia dalam Menghadapi Pandemi Virus Corona (Covid-19) dan Kiat Menjaga Kesejahteraan Jiwa," Salam: Jurnal Sosial dan Budaya Syar-i, Volume 7, No. 3 (2020).

[2] Yunus, N.R.; Rezki, Annissa. "Kebijakan Pemberlakuan Lock Down Sebagai Antisipasi Penyebaran Corona Virus Covid19," Salam: Jurnal Sosial dan Budaya Syar-i, Volume 7, No. 3 (2020).

[3] M. Leisner and P. Brune, "GoodBye Localhost: A Cloud-Based Web IDE for Teaching Java EE Web Development to NonComputer Science Majors," 2019 IEEE/ACM 41st International Conference on Software Engineering: Companion Proceedings (ICSE-Companion), Montreal, QC, Canada, 2019, pp. 268-269.

[4] Y. Rajul, D. S. Babu and K. Anuradha, "Analysis on Periodic Web Personalization for the
Efficiency of Web services," 2018 Second International Conference on Inventive Communication and Computational Technologies (ICICCT), Coimbatore, 2018, pp. 1-6.

[5] Fakhru, Muhammad. (2014), Pengaruh Promosi dan Harga Terhadap Minat Beli Perumahan Obama PT.Nailah Adi Kurnia Sei Mencirim Medan. Jurnal Manajemen dan Bisnis. 14(2), 139. [6] Trivena \& Agus. 2016, Evaluasi Strategi Promosi dan Penjualan Terhadap Keunggulan Bersaing Pada PT. Astragraphia,TBK Cabang Manado. Jurnal EMBA. 4(2), 134.

[7] M. Dawodi, M. H. Hedayati, J. A. Baktash and A. L. Erfan, "Facebook MySQL Performance vs MySQL Performance," 2019 IEEE 10th Annual Information Technology, Electronics and Mobile Communication Conference (IEMCON), Vancouver, BC, Canada, 2019, pp. 0103-0109.

[8] I. Zoratti, "MYSQL Security Best Practices," 2006 IET Conference on Crime and Security, London, 2006, pp. 183-198.

[9] Z. Xiang, C. Che and S. Tang, "Model of Promotion Cost Distribution of Telecommunication Operators and Study on the Promotion Effects Based on Artificial Neural Neworks," 2009 International Conference on New Trends in Information and Service Science, Beijing, 2009.

[10] Zeng Kaisheng, "Online sales promotion and impulse buying online in the E-business age: A theoretical model approach," 2011 IEEE 2nd International Conference on Software Engineering and Service Science, Beijing, 2011, pp. 618-621.

[11] X. S. Hu, R. C. Murphy, S. Dosanjh, K. Olukotun and S. Poole, "Hardware/software co- 
design for high performance

computing: Challenges and

opportunities," 2010

IEEE/ACM/IFIP International

Conference on Hardware/Software

Codesign and System Synthesis

(CODES+ISSS), Scottsdale, AZ, 2010, pp. 63-64.

[12] IEEE Standard for SoftwareHardware Interface for MultiMany-Core," in IEEE Std 28042019 , vol., no., pp.1-84, 24 Jan. 2020

[13] Syahputra E.R., Sembing B.O., Dewi A.R., Hasdiana H. and Maulana H. 2018 Ads block management system using open Virtual Private Network on Ubuntu operating system International Journal of Engineering Technology 7 58-61 20182018 